\title{
Review
}

\section{Refugees and the myth of human rights: Life outside the pale of the law}

\author{
Emma Larking \\ Ashgate, Farnham, 2014, iv+199 pp., ISBN: 978-1472430076
}

Contemporary Political Theory (2017) 16, 597-599. doi:10.1057/s41296-017-0139-6; advance online publication 25 July 2017

In this careful attempt to 'think what we are doing' in the treatment by liberal states of refugees and asylum seekers (Arendt, 1998, p. 5, cited on p. 1), Emma Larking sets out to argue for the entitlement of refugees to real, rather than mythical rights. Larking starts from an 'expansive refugee definition' (pp. 2-3), although the primary focus of the book is said to be 'those refugees at the state's border or living on its territory' (p. 3). Larking acknowledges that this risks obscuring 'the plight of those refugees living in other parts of the world' (p. 3), without explicitly acknowledging that this is the situation of the vast majority of refugees, in part because of the enormous efforts expended by liberal states.

The book's starting point is 'the myth of human rights'. Larking argues that the treatment of refugees by the liberal state shows human rights' worthlessness. Heavily inspired by Hannah Arendt, she argues from the off that their emptiness is degrading not only to those forced to rely on them, but also to the promised equality of the rule of law. From this, she works towards her concluding claim that refugees must be provided with recognised legal status in a given state, and her sketch of two international mechanisms that might facilitate this.

In her Introduction, Larking spends time interpreting Arendt's use of the phrase 'outside the pale of the law' (pp. 6-7). To be 'beyond the pale', in its historical meaning, is to be physically outside of the scope (and protection) of a particular legal jurisdiction. In this book, Larking revives this phrase, showing how refugees today are kept physically 'beyond the pale', as well as how liberal regimes have maintained an abject space in which they can be physically present, yet remain outside of the law's protective force. This, indeed, is the situation of refugees whose 'unlawful or legally qualified presence ... exposes them to arrest and detention or deportation' (p. 120). These harsh and degrading policies are clearly and violently at odds with the commitments of liberal states, and Larking spends the majority of the book addressing the tensions in the liberal project.

Part one of the book (Chapters 1-3) deals with Arendt, focusing primarily on her work in The Origins of Totalitarianism on 'the decline of the nation-state and the end

(C) 2017 Macmillan Publishers Ltd. 1470-8914 Contemporary Political Theory Vol. 16, 4, 597-599 www.palgrave.com/journals 
of the rights of man' and on her accounts of politics in On Revolution and The Human Condition. These chapters provide helpful summaries of Arendt's key claims in respect of refugees, rights, and politics. At times in this section, the discussion felt descriptive of Arendt's perspective, rather than Larking's. Even so, part one clearly demonstrates the implications of being outside the pale of the law, as well as the myth of human rights. In concluding this part of the book, Larking argues that the experience of being beyond the pale, and the myth of human rights, demonstrate that morality is a poor substitute for 'the realm of justice or right' (p. 62). This sets the scene for the remainder of the book, in which she advances the argument that 'all who are subject to the coercive power of the state must be entitled to recognition under its constitutive law' (p. 63). However, to my mind, the dilemmas articulated by Arendt, and re-articulated by Larking, limit the scope for realisation of this entitlement. That is to say, that while it may be clear " $w h y$ the consistency and integrity of the law must be preserved' (p. 63), 'the political conditions that make the attribution of rights possible' are more difficult to understand, let alone bring about. This is in keeping with Larking's own claim about 'the political efforts and commitment necessary' (p. 1). However, it does leave questions - not just for Larking, but for all of us interested in the prospects - about the sources of this commitment.

Part two of the book (Chapters 4-6) addresses in more depth 'the false promise' of liberalism in terms of universality. The function here is to further problematise the relationship between equality, law, and the state, and to demonstrate once more the limits to natural, or moral, rights relative to the membership rights of political communities. The discussion in these chapters is rich, and critical, although the implications for refugees might, in my view, have been signposted more explicitly in order to help connect the dots for the reader.

Chapter 4 addresses the philosophy of natural law and natural right, ahead of the discussions of Locke and Kant in Chapters 5 and 6, respectively. The philosophical discussion here, as in part one, raises a range of interesting and pertinent points about the relationship between liberalism, law and universality. Contrary to recent work in political theory seeking to revive Kantian hospitality as a pathway to cosmopolitanism, the conclusion to part two argues that Kant, too, is part of a liberal tradition which, 'despite its use of the language of moral universalism, accords distinctive status to political communities and to their members' (p. 115). It remains, then, for part three of the book to sketch an alternative, and here she shifts back to the twenty-first century world in which refugees are kept beyond the pale.

In the third part of the book, Larking returns to the situation of contemporary refugees, situating them within the dual framework of state sovereignty and the international human rights regime. She makes a persuasive argument about the reproduction of the pale of the law by the refugee and human rights regimes, building on her earlier account of 'the myth of human rights'. Her skepticism about the ostensibly cosmopolitan character of today's world is well argued, and she demonstrates well the importance of recognition to legal personality. Chapter 7 
outlines the situation of the rightless, in, or at the border of liberal states, who are objects, but not subjects of their laws. In Chapter 8, Larking shifts to the international order which constitute states as sovereign communities, outlining the gaps which the current order produces. By this point, Larking has painstakingly shown how the myth of human rights is central to the nation state (part one), liberal political philosophy (part two) and to the contemporary global order (part three). The challenges for implementing the rights of refugees could hardly be clearer. In Chapter 9, Larking sketches an alternative path.

In that final chapter of the book, Larking argues that in spite of the failings of existing international institutions, we have a global politics constitutive of a world community in which she sees the conditions for 'a new law on earth' (p. 151). Her vision avoids the troubled foundations of 'natural' and 'human' rights, founding its hopes instead on 'the political agency of individual members' of 'the universal human polity' (p. 168). The question I was left with by the end of the book was whether this foundation - any more than 'human' rights - can be reconciled with the existing order. Larking imagines a global Citizenship Convention 'providing legal status and citizenship to victims of genocide' (p. 164), in which states parties or a UN body would serve as 'representatives of all humanity'. This would be supplemented by a multi-lateral refugee resettlement treaty (p. 165), and a greater commitment to global distributive justice (p. 166). Taken together, these measures would provide meaningful rights to refugees, mitigate the push factors for migration, and prevent 'the collapse of the rule of law within states' (p. 165). And yet, so convincing was the weight of the book on the centrality of 'the pale' to law, political community, and to world order, that I was, regrettably, not persuaded that refugees do constitute a political (rather than moral) threat to the rule of law within states. Neither was it clear what these global structures would do for those refugees beyond the pale in the sense of being within the liberal state, but excluded from it. If the consent-based institutions she outlines were created, it is at least plausible that they would have the unintended consequence of sharpening the division between 'good' refugees who wait for resettlement and 'bad' or 'illegal' spontaneous arrivals. This would potentially exacerbate, rather than mitigate the abjection of being 'outside the pale of the law'.

Even so, the book offers a detailed and timely reflection on the inequalities sustained by domestic and international practices, and on the implications for refugees. I will follow with interest her research in this area, and in particular on the potential for the 'universal human polity' to afford 'the right to citizenship to all people' (p. 168).

Kelly Staples

University of Leicester, Leicester LE1 7RH, UK

kls25@le.ac.uk 